Çukurova Üniversitesi Mühendislik Fakültesi Dergisi, 36(1), ss. 55-62, Mart 2021

Cukurova University Journal of the Faculty of Engineering, 36(1), pp. 55-62, March 2021

\title{
The Factors Causing Height-Fall Accidents Occurring During Roofing and Facing Works
}

\author{
Olcay GENÇ" ${ }^{* 1}$ Gülgün MISTIKOĞLU², Onur YILDIZ ${ }^{3}$, Ercan ERDİ̧̧ ${ }^{4}$ \\ ${ }^{1}$ İskenderun Teknik Üniversitesi, Müh. ve Doğa Bilimleri Fakültesi, İnşaat Mühendisliği Bölümü \\ ${ }^{2}$ Mustafa Kemal Üniversitesi, Mimarlık Fakültesi, Mimarlı Bölümü, Hatay \\ ${ }^{3}$ Doğu Akdeniz Kalkınma Ajansi, Hatay \\ ${ }^{4}$ İskenderun Teknik Üniversitesi, Mimarlık Fakültesi, Mimarlık Bölümü, İskenderun
}

Geliş tarihi: 04.01.2021 Kabul tarihi: 31.03.2021

\begin{abstract}
In order to take the necessary safety measures and to minimize the risk of accidents that may occur during the production, dismantling, and repair of roof and facade cladding systems, during the design process, it is necessary to analyze the prominent accident types and their causes with numerical data. In this study, concerning construction sector, the principal factors affecting fall accidents occurring during roofing and facing works are investigated by a questionnaire survey. Exploratory Factor Analysis (EFA) is utilized to analyze the survey results. The results of the EFA identify three key factors; (1) business culture and inappropriate workplace, (2) dynamic and unstable external effects, and (3) job analysis. As a result of this study, the main factors affecting the accidents of falling from height during roofing and facing works are identified and contribution is made to the selection of appropriate protection methods for the practitioners.
\end{abstract}

Keywords: Construction sector, Height-fall accidents, Roofing and facing works, Work accidents

\section{Çatı ve Cephe Kaplama İşlerinde Meydana Gelen Yüksekten Düşme Kazalarına Sebep Olan Faktörler}

Öz

Çatı ve cephe kaplama sistemlerinin imalatı, sökümü ve onarımı sırasında oluşabilecek kaza risklerinin minimize edilmesi ve gerekli emniyet tedbirlerinin alınması için, daha tasarım sürecinde, ön plana çıkan kaza tiplerinin ve nedenlerinin neler olduğunun sayısal verilerle analiz edilmesi ve alınabilecek önlemlerin neleri kapsaması gerektiğinin belirlenmesi gerekmektedir. Bu çalışmada, inşaat sektöründe çatı ve cephe kaplama işleri sırasında meydana gelen düşme kazalarının sebeplerini tespit etmek için bir anket çalışması uygulanmıştır. Anket verilerine Açımlayıcı Faktör Analizi (AFA) uygulanmıştır. AFA' nın sonuçlarından üç temel faktör tespit edilmiştir. Çatı ve cephe kaplama işlerinde meydana gelen yüksekten düşme kaynaklı kazaların ana sebepleri; (1) iş kültürü, (2) dinamik ve istikrarsız dış çevre ve (3) iş analizi olarak belirlenmiştir. Bu çalışma sonucunda, çatı ve cephe kaplama işleri sırasında meydana gelen yüksekten düşme kazalarını etkileyen ana faktörler belirlenmiş ve uygulamacılara uygun korunma yöntemlerinin seçilmesinde katkı sağlanmıştır.

Anahtar Kelimeler: Çatı ve cephe kaplama işleri, Yüksekten düşme kazaları, İnşaat sektörü, İş kazaları

*Sorumlu yazar (Corresponding author): Olcay GENÇ, olcay.genc@iste.edu.tr 


\section{INTRODUCTION}

The rate of fatal accidents in construction sites, which are more likely to encounter potential risks, is twice as high as the average of all sectors [1]. In our country, an average of 20 occupational accidents occurs in the construction sector every working day, and an average of 1 person is permanently disabled or dies [2]. Most of these accidents resulting in death or permanent incapacity occur as a result of falling from a height, especially during the production, dismantling, and repair of roofs and facade coverings [3]. When the fall height and the death rate of accidents are evaluated, it is seen that falls from a height of 10 meters and above result in death at a rate of $19.6 \%$, and below 1.8 meters this rate decreases to $8.2 \%$ [1]. On the other hand, the fatality rate of falling from the roof is $30 \%$, while it is $24 \%$ in falling from stairs, $15 \%$ in falling from scaffolding, $7 \%$ in falling from stationary lifting vehicles, and 5\% in falls on the ground level [1]. Labors that work in the production dismantling and repair of the roof and facing work, usually as a result of their carelessness/inability to focus on their work or their colleagues, their imprudence and external environmental conditions; are faced with accidents resulting in injury or death by falling from edges of the roof, places with gaps or openings, water collecting surfaces, walls and eaves, fragile parts such as roof lights or from the pier [4]. Also, the inability of workers to safely reach the workplace, failure to take precautions to prevent unqualified personnel from entering the dangerous areas under and around the part where the work is carried out, failure to take necessary measures to prevent injuries caused by falling materials, not using suitable equipment such as garbage chimney, freight elevator or crane during the unloading of materials, and allowing the materials to accumulate in places where they can fall during the manufacture of roof and facade coatings - not properly stored can cause these accidents $[5,6]$.

There are different studies in the literature, such as surveys, interviews, case studies, observations, and controlled laboratory experiments in various disciplines, to understand the causes of falls from height in the construction industry. Liy et al. (2016), with a survey they applied to construction companies in the Kuching region of Malaysia, emphasized the difficulties in communication related to the main cause of accidents that occur as a result of falling from heights, especially on roofs and piers [7]. The results of their study suggest that roof falls and scaffolding falls are responsible for most fall hazards where the communication barrier is the key issue that causes the fall hazards. Baran and Esen (2016) stated the importance of risk analysis before the construction of high-rise buildings and the application of correct working and protection methods during construction [8]. Akarsu (2016) examined 100 work accident reports of the Labor Inspection Board, and conducted a risk assessment study on the reasons in terms of frequency, importance, and risk, and examined what should be the priorities and preventive actions in response to these accidents [9]. In the study; it was stated that the most accidents occurred in April and September, which are indicated as the months when the building sector was revived, employees between the ages of 25-34 were exposed to accidents, and carelessness and imprudence were observed more in employees under 35, and accidents mostly occurred at the start and end hours of work. Kanan et al. (2018) emphasized that in order to minimize occupational accidents that cause deaths and injuries, real-time autonomous systems that will ensure safety in construction sites should be designed and developed, and these systems should include different technological elements such as sensors, robotics, laser scanning [10].

This paper aims at examining the principal factors affecting fall accidents in construction sector occurring during roofing and facing works by utilizing Exploratory Factor Analysis (EFA) method.

The remainder of this paper is organized as follows. Section 2 presents the research data used in the study. Section 3 describes the methodology used in this study. Section 4 provides the results of EFA. Section 5 discusses the findings, and finally, Section 6 provides conclusions. 


\section{RESEARCH DATA}

The data analyzed in this study is derived from a master thesis [1]. In the thesis, a web-based questionnaire is prepared and delivered to the civil engineers who work for the public or private sectors in Turkey via the chamber of civil engineers. The questionnaire, which is designed for a 5-point Likert scale (1- extremely low to 5extremely high), consists of two parts: (1) the variables and related reasons for fall accidents, and (2) demographic questions. The variables are presented in Table.

Table 1. The variables related to the reasons for fall accidents

\begin{tabular}{|l|l|l|}
\hline No & Code & Name \\
\hline 1 & VAR1 & $\begin{array}{l}\text { Employees' failure to adopt a safe } \\
\text { business culture for various reasons }\end{array}$ \\
\hline 2 & VAR2 & $\begin{array}{l}\text { Roofing and cladding jobs require } \\
\text { different postures }\end{array}$ \\
\hline 3 & VAR3 & $\begin{array}{l}\text { Insufficient use of personal } \\
\text { protective equipment }\end{array}$ \\
\hline 4 & VAR4 & Lack of inspection \\
\hline 5 & VAR5 & $\begin{array}{l}\text { Noncompliance with the related } \\
\text { legislation }\end{array}$ \\
\hline 6 & VAR6 & $\begin{array}{l}\text { The unwillingness of the employer } \\
\text { on occupational health and safety } \\
\text { issues }\end{array}$ \\
\hline 7 & VAR7 & Using inappropriate work platform \\
\hline 8 & VAR8 & $\begin{array}{l}\text { Failure to comply with occupational } \\
\text { ethics }\end{array}$ \\
\hline 9 & VAR9 & Adverse weather conditions \\
\hline 10 & VAR10 & Inadequacies in legal legislation. \\
\hline & & $\begin{array}{l}\text { Not paying attention to the sorting } \\
\text { and arranging of materials and } \\
\text { equipment that are not needed } \\
\text { during the production of roofing and } \\
\text { facade }\end{array}$ \\
\hline 11 & VAR \\
\hline
\end{tabular}

\section{METHODOLOGY}

This study investigates the principal factors affecting construction fall accidents occurring during roofing and facing works by means of Exploratory Factor Analysis (EFA) of the data adopted from an MSc thesis using IBM SPSS.

The evaluation method for analyzing the factors affecting construction fall accidents is addressed in the following subsection 3.1. in which an explanation of EFA used in this study is captured.

\subsection{Exploratory Factor Analysis (EFA)}

Factor analysis is a statistical method in which a large number of highly correlated observed variables are explained with a small number of factors that are not correlated, considering the correlations between variables [11]. In order to increase interpretability and to define hidden data systems, the main purpose of this technique is to reduce the number of variables calculated to smaller parameters [12]. In order to interpret the factor analysis; the number of observed individuals must be greater than the number of variables. Bartlett's sphericity test was used to calculate the multivariate normality of the variables, while the Kaiser-Meyer-Olkin (KMO) test was used to measure whether the distribution of values is sufficient for performing EFA. KMO value is interpreted as follows: 0.90 is perfect, $0.89-0.80$ is very good, $0.79-0.70$ is good, $0.69-0.60$ is moderate, $0.59-0.50$ is poor, $<0.50$ is rejected and it is decided whether to continue the analysis or not accordingly. In factor analysis (FA), it is assumed that all variables and all linear components of these variables are normally distributed. This is checked by the Bartlett Test of Sphericity. If the significance is zero, the correlation matrix is not an identity matrix and the analysis continues. If there is no correlation exceeding 0.30 in the correlation matrix in factor analysis, its use will not be appropriate. Bartlett sphericity test result of the data shows statistical significance $(p<0,05)$ and $\mathrm{KMO}$ value $(0,784)$ indicates the eligibility $(>0,5)$ of the data for EFA [13].

The principal component analysis is used as the extraction method in order to carry out the EFA. The principal variables for each factor are described and used as explanatory measures to explain the importance of a factor. These main variables are selected on the basis of two parameters; (1) eigenvalue $\geq 1$, and (2) loading values of variables should be a minimum 0.3 . 


\section{RESULTS}

The sample size of the study is 151 civil engineers. $\% 75$ of the participants have more than 5-year work experience. 1. As a result of EFA, three factors that explain $57,960 \%$ variance are extracted. Table 2 presents these factors and their representative variances. Table 3 demonstrates the configuration of the factors and loadings of the extraction of the principal factors. It is clear that, with the exception of one variable, the loadings of the key variables described for each extracted factor are greater than 0,5 , reflecting the important contribution of each variable to the extracted factor. The variable VAR3 is out of the analysis.

Table 2. Factors and total variance explained

\begin{tabular}{|c|c|c|c|}
\hline \multirow{2}{*}{ Component } & \multicolumn{3}{|c|}{ Initial Eigenvalues } \\
\cline { 2 - 4 } & Total & \% of Variance & Cum. \% \\
\hline 1 & 3,321 & 33,210 & 33,210 \\
\hline 2 & 1,381 & 13,813 & 47,023 \\
\hline 3 & 1,094 & 10,937 & 57,960 \\
\hline \multirow{3}{*}{ Component } & Extraction Sums of Squared \\
Loadings \\
\cline { 2 - 4 } & Total & $\begin{array}{c}\text { \% of } \\
\text { Variance }\end{array}$ & Cum. \% \\
\hline 1 & 3,321 & 33,210 & 33,210 \\
\hline 2 & 1,381 & 13,813 & 47,023 \\
\hline 3 & 1,094 & 10,937 & 57,960 \\
\hline \multirow{2}{*}{ Component } & Rotation Sums of Squared Loadings \\
\cline { 2 - 4 } & \multicolumn{3}{|c|}{ Total } \\
\hline 1 & \multicolumn{3}{|c|}{2,720} \\
\hline 2 & \multicolumn{3}{|c|}{1,439} \\
\hline 3 & \multicolumn{3}{|c}{} \\
\hline
\end{tabular}

Table 3. Factor structure and loadings of the principal factor extraction

\begin{tabular}{|c|c|c|c|}
\hline & \multicolumn{3}{|c|}{ Component } \\
\cline { 2 - 4 } & 1 & 2 & 3 \\
\hline VAR1 & 0,841 & & \\
VAR5 & 0,790 & & \\
VAR8 & 0,657 & & \\
VAR6 & 0,625 & & \\
VAR7 & 0,567 & & \\
VAR4 & 0,464 & & \\
VAR10 & & 0,766 & \\
VAR9 & & 0,696 & \\
VAR2 & & & 0,817 \\
VAR11 & & & 0,656 \\
\hline
\end{tabular}

An effective aggregate name is given to any extracted factor to reflect the interaction of all variables within it. Table 4 displays the extracted risk factors and their associated variables. This is the order of the related variables, based on the proportion of variance; (1) business culture and inappropriate workplace, (2) Dynamic and unstable external effects, and (3) job analysis.

Table 4. Extracted risk factors and their related variables

\begin{tabular}{|c|c|}
\hline Factor & Variables \\
\hline $\begin{array}{l}\text { Business } \\
\text { culture and } \\
\text { inappropriate } \\
\text { workplace }\end{array}$ & $\begin{array}{l}\text { Employees' failure to adopt a safe } \\
\text { business culture for various } \\
\text { reasons } \\
\text { Noncompliance with the related } \\
\text { legislation } \\
\text { Failure to comply with } \\
\text { occupational ethics } \\
\text { The unwillingness of the } \\
\text { employer on occupational health } \\
\text { and safety issues } \\
\text { Using inappropriate work } \\
\text { platform } \\
\text { Lack of inspection }\end{array}$ \\
\hline $\begin{array}{l}\text { Dynamic and } \\
\text { unstable } \\
\text { external effects }\end{array}$ & $\begin{array}{l}\text { Inadequacies in legal legislation } \\
\text { Adverse weather conditions }\end{array}$ \\
\hline Job analysis & $\begin{array}{l}\text { Roofing and cladding jobs } \\
\text { require different postures } \\
\text { Not paying attention to the } \\
\text { sorting and arranging of materials } \\
\text { and equipment that are not } \\
\text { needed during the production of } \\
\text { roofing and facade }\end{array}$ \\
\hline
\end{tabular}

The first factor "business culture and inappropriate workplace" reflects the largest total variance $(\% 33,210)$. It consists of six variables; employees' failure to adopt a safe business culture for various reasons, noncompliance with the related legislation, failure to comply with occupational ethics, the unwillingness of the employer on occupational health and safety issues, using inappropriate work platform, and lack of inspection. The second factor "dynamic and unstable external effects" represents \%13,813 of the total variance and consists of two variables; inadequacies in legal legislation, and adverse weather conditions. The third factor "job analysis" explains the \%10,937 variances. This factor also 
includes two variables; roofing and cladding jobs require different postures, and not paying attention to the sorting and arranging of materials/ equipment that are not needed during the production of roofing and facade.

\section{DISCUSSION}

This section discusses the findings of the study. Firstly, Factor 1 is addressed. This is followed by Factor 2 and Factor 3.

Factor 1: Business culture and inappropriate workplace

The "business culture and inappropriate workplace" factor covers the most variables and is considered by civil engineers to be the most significant factor. The fact that human and human behavior constitutes an important element in work accidents reveals the importance of the concept of occupational safety culture. Due to the characteristics of the construction industry, it is a very difficult task to create and maintain a culture of occupational safety in this sector. The variable of the business culture and inappropriate workplace factor, employees' failure to adopt a safe business culture for various reasons, has the highest loading score $(0.841)$. In the construction sector, one of the main reasons for failure to adopt a safe business culture is $\mathrm{s}$ work pressure on contractors and their employees who aim to comply with time and cost commitments or deliver work ahead of time in construction work. [14]. Reducing the pressure in construction works may play an essential role in creating a culture of safety. The second and third variables of the factor are noncompliance with the related legislation and failure to comply with occupational ethics with the loading values of 0.790 and 0.657 , respectively. Although ethical behavior includes compliance with the rules of legislation, it also requires interpreting the provisions of the legislation that may not comply with the understanding of law in a way that will provide legal practices within the scope of their initiative and make an effort to make these provisions legal [15]. Thus, there is a strong relationship between complying with the rules of legislation and ethics. The solutions to be produced by investigating the underlying causes of these variables can create remedies for both problems. The fourth variable out of six is the unwillingness of the employer on occupational health and safety issues with a loading value of 0.625 . Qualifying an incident as a work accident does not require the employer to be held responsible for this accident in all cases. In order for the employer to be responsible for an accident within the scope of the Social Insurance Law, the accident must have occurred as a result of the employer's behavior or possibility contrary to the obligation to take occupational safety measures and show care, in other words, the employer's fault must be proven to be responsible for the accident [16]. Not using personal protective equipment is seen as one of the main causes of work accidents. The results of this study show that the opposite is also true. In other words, not only the employees but also employers have unwillingness on occupational health and safety issues. The main purpose of occupational health and safety supervision is to prevent occupational diseases and occupational accidents and to ensure a healthier implementation of legal regulations regarding occupational health and safety [17]. Consequently, increasing the inspections, or updating audit strategies if the inspections are sufficient, can remedy this problem. The fifth variable of the business culture and inappropriate workplace factor is "using the inappropriate working platform" with a loading value of 0,567 . This is in line with the study of [18] which indicates that one of the main reasons that cause falling from heights and fatal accidents in construction works is the failure to take necessary precautions against falling in the scaffoldings, e.g., lack of necessary railings, and not fixed to the ground appropriately. The use of collective protective equipment, safety nets, and most importantly, the proper construction of the scaffolding are among the first steps to prevent this problem [19]. The sixth and last variable is "lack of inspection" with a loading value of 0.464 . Official inspection is essential in order to prevent occupational accidents that may occur in the 
workplace. In many countries, there are institutions that oversee the implementation of laws related to occupational safety. The authority to conduct and regulate official inspections in our country is exercised by the inspectors affiliated with the Labor Inspection Board. It is clear that the inspections on occupational health and safety in our country are not at the desired level [20]. In this direction, inspections and penalties should be increased, companies that have not adopted the understanding of occupational safety should be announced to the public effectively [21].

Factor 2: Dynamic and unstable external effects

In order to prevent or minimize work accidents, with the Occupational Health and Safety Law No. 6331 (2012); duties, powers, and responsibilities of employers and employees are regulated in order to ensure occupational health and safety at workplaces and to improve existing health and safety conditions. Then, with the relevant regulations, the requirements for occupational health and safety for employers and employees are explained. It is the first and only independent law enacted in terms of addressing the concept of "protection of health and safety" of all employees, with some exceptions [22]. However, the first variable of the factor is "inadequacies in legal legislation" with a loading value of 0.766 . In many cases, the main problem is that the laws are not implemented rather than inadequate. Employer obligations, which are dealt with in the Occupational Health and Safety Law and its relevant regulations, can be considered sufficient to establish health and safety in the workplace if applied effectively [22]. Risky behaviors, individual features, site environments, operational characteristics, agents (scaffolds/ladders), and weather conditions are the most prevalent variables associated with falling from height [23]. Adverse weather conditions are the second variable of the dynamic and unstable external effects factor. In order to prevent occupational accidents caused by bad weather conditions, it is necessary to pay more attention and inspect occupational health and safety practices in winter and summer when the weather conditions are adverse [24].
Factor 3: Job analysis

Depending on the design of the work, different stance configurations can be needed for construction work. The first variable of the job analysis factor is "Roofing and cladding jobs require different postures" with a loading value of 0.817 . Working at height and indifferent posture positions is a situation that requires a separate skill and experience. Analysis of such jobs should be well performed and the most appropriate employees should be used for such jobs. The second variable is "not paying attention to the sorting and arranging of materials and equipment that are not needed during the production of roofing and facade" with a loading value of 0.656 . Sorting helps remove faulty instruments, scrap, and outdated jigs and fixtures and makes the movement of products faster and simpler for workers to operate and travel [25].

\section{CONCLUSION}

In this paper, a systematic analysis of the main factors affecting fall accidents in construction sector occurring during roofing and facing works is presented. From the questionnaire survey conducted with 151 civil engineers in Turkey, the main factors are identified by exploratory factor analysis (EFA). The interpretation of the EFA results offers such an insight that allows the key factors of the construction sector to be examined in relation to fall accidents that occur during roofing and facing work. The exploratory results of this study show that the results of the EFA identify three key factors namely; (1) business culture and inappropriate workplace, (2) dynamic and unstable external effects, and (3) job analysis. The theoretical contribution of this paper is in the form of a questionnaire study to the construction management knowledge base in which the study illustrates how the main factors affecting fall accidents in construction sector occurring during roofing and facing works and related variables of the construction sector are identified, hence supporting selecting appropriate prevention method. This contribution provides practitioners with a tool for decision making in construction site management with respect to the identification and 
selection of prevention to minimize the fall-related work accidents of the construction projects.

\section{REFERENCES}

1. Yildiz, O., 2019. Çatı ve Cephe Kaplamalarında Yüksekten Düşmeyi Etkileyen Faktörlerin Analizi, İskenderun Teknik Üniversitesi, Mühendislik ve Fen Bilimleri Enstitüsü, Yüksek Lisans Tezi, Hatay, 98.

2. Müngen, U., 2011. İnşaat Sektörümüzdeki Başlica İş Kazası Tipleri, TMH. 469, 32-39.

3. Kines, P., 2001. Occupational Injury Risk Assessment Using Injury Severity Odds Ratios: Male Falls From Heights In The Danish Construction Industry, 1993-1999. Human And Ecological Risk Assessment: An International Journal, 7(7), 1929-1943.

4. ÇSGB, 2015. Yüksekten Düşmeye Karş1 Güvenli Çalışma, İnşaatlarda İSG Serisi-3.

5. Mistıkoğlu, G., Erdis, E., Genc, O., Yıldız, O., 2016, Çatı ve Cephe Kaplamalarında Yüksekten Düşmeyi Etkileyen Faktörlerin Analizi, Türkiye Muhendislik Haberleri, 489.

6. Mistıkoğlu, G., Erdis, E., Genc, O., Yıldız, O., 2015. Çatı ve Cephe Kaplamalarında Yüksekten Düşmeyi Etkileyen Faktörlerin Analizi, In: Izmir Insa. Muh. Odasi 5. İşçi Sağliği ve İş Güvenliği Sempozyumu, TR.

7. Liy, C.H., Ibrahim, S.H., Affandi, R., Rosli, N.A., Nawi, M.N.M., 2017. Causes of Fall Hazards in Construction Site Management, International Review of Management and Marketing, 6(8S), 257-263.

8. Baran, Y., Esen, Y., 2016. Çatı ve Cephe Sistemlerinin Yapım ve Onarım Süreçlerinde İş Güvenliği, In: 8. Ulus. Çatı ve Cephe Sempozyumu, İstanbul, Turkey, 195-202.

9. Akarsu, D., 2016. Yüksekten Düşme Kazaları Üzerine Risk Değerlendirmesi, Çalışma ve Sosyal Güvenlik Bakanlığı, İș Sağlığı ve Güvenliği Genel Müdürlügüu, İş Sağlığ1 ve Güvenliği Uzmanlık Tezi, Ankara, 89.

10. Kanan, R., Elhassan, O., Bensalem, R., 2018. An Iot-Based Autonomous System for Workers' Safety In Construction Sites with Real-Time Alarming, Monitoring, and Positioning Strategies, Automation In
Construction. 88, 73-86.

11. Özgür, E., 2003. Çok Değişkenli İstatistiksel Analiz Yöntemleri ve Bir Uygulama, Gazi Üniversitesi, Sosyal Bilimler Enstitüsü, Doktora Tezi, 173.

12. Jadidoleslami, S., Saghatforoush, E., Zare Ravasan, A., 2018. Constructability Obstacles: An Exploratory Factor Analysis Approach, International Journal of Construction Management, 1-14.

13. George, D., Mallery, P., 2007. SPPS for Windows Step By Step: A Simple Guide and Reference, (Fourth Edition 11.0 update), Pearson A and B, 63 .

14. Akdoğan, Z.D., 2019. Küçük ve Orta Ölçekli Inşaat Firmalarında İş Güvenliği Kültürü, Balıkesir Üniversitesi, Fen Bilimleri Enstitüsü, Yüksek Lisans Tezi, 93.

15. Özgür, B., 2010. Kamu Yönetimi Denetçilerinde Etik Kültürün Geliştirilmesi, Denetişim Dergisi, 5, 1-18.

16. Güzel, A., Deniz, U., 2012. İşverenin İş Kazasından Doğan Sorumluluğunun Niteliği ve Sınırları (Karar İncelemesi), Çalışma ve Toplum, 34(3), 157-188.

17. Parlak, T.M., Olcay, Z.F., 2016. İş Sağlığı ve Güvenliği Denetimi Türkiye ve İngiltere Örneklerinin Karşılaştırmalı İncelenmesi, Anadolu Bil Meslek Yüksekokulu Dergisi, (41), 81-97.

18. Görücü, M.N., Müngen, U., 2011. Yapi İş Kolunda Devletin İş Sağliği ve Güvenliği Denetimi ve "İnşaatlarda Yüksekten Düşmelerin Önlenmesi Projesinin" Değerlendirilmesi”, In: 3. İşçi Sağliği ve İş Güvenliği Sempozyumu.

19. Öztürk, E., Şimşek, H., 2020. Çatı İşlerinde İşçi Sağlığ1 ve Güvenliği 5x5 Matris Yöntemiyle Risk Değerlendirmesi, İSG Akademik, 2(1), 59-71.

20. Atasever, F., Coşkun, H., Genç, O., Erdiş, E., 2015. Adana İli Özelinde İnşaat Şantiyelerinde İş Güvenliği Resmi Denetiminin İşlevselliği Algısı, In: 8. Ulus. İşçi Sağlığı ve İş Güvenliği Kongresi, Adana, 43-50.

21. Usmen, M., Baradan, S., 2011. İnşaat Sektöründe İşçi Sağlığı ve İş Güvenliği Alanındaki İyileştirmeleri Etkileyen Faktörler: ABD Örneği, TMH, 469(5), 40-48. 
22. Boz Eravcı, D., 2019. 6331 Sayılı İş Sağlığı ve Güvenliği Kanunu ve İlgili Yönetmelikleri Çerçevesinde İşverenin Yükümlülükleri, Hak İş Uluslararası Emek ve Toplum Dergisi, 8(22), 330-355.

23. Nadhim, E.A., Hon, C., Xia, B., Stewart, I., Fang, D., 2016. Falls from Height in the Construction Industry: A Critical Review of the Scientific Literature, International Journal of Environmental Research and Public Health, 13(7), 368.

24. Ateş, E., Aytaç, N., 2019. Adana'da Bir İnşaat Firmasında İş Kazalarının ve Çalışma Koşulları ile İlişkisinin Değerlendirilmesi, Sakarya Tıp Dergisi, 9(4), 661-668.

25. Gupta, S., Jain, S.K., 2015. An Application of $5 \mathrm{~S}$ Concept to Organize the Workplace at a Scientific Instruments Manufacturing Company, International Journal of Lean Six Sigma, 6(1), 73-88. 